\title{
Analysis Of Technopreneurship Applications In
}

\section{Alternative Energy Company:}

\section{Study On Cv. Wahana Putera Ideas, Bandung}

\author{
Ida Nurnida ${ }^{1}$, Eko Kurnia Wicaksono ${ }^{2}$, \\ ${ }^{1}$ Business Administration, School of Communication and Business, Telkom University, Bandung, Indonesia \\ ${ }^{2}$ Business Administration, School of Communication and Business, Telkom University, Bandung, Indonesia \\ idanurnida@gmail.com (Ida Nurnida),icak.8389@gmail.com (Eko Kurnia Wicaksono),
}

\begin{abstract}
At this time, some people are still reluctant and afraid to use LPG gas stove, because in addition to the many cases of explosions, this type of stove is also rare in the market. These conditions require people to find other alternatives to meet their needs. On the other hand, in the business world, the concept of technopreneurship becomes one of the solutions that can bridge the economic interests through technology, especially in the field of alternative energy. One company that has been using this technopreneurship concept is CV Wahana Putera Ideas as an energy manufacturing company.

This research was conducted with the aim to know the application of technopreneurship concept which cover aspects of business skill and technology skill at CV Wahana Putera Ideas. The type of this research is descriptive with qualitative approach. Data collection techniques used observation, interviews, and related document collection, while processing and data analysis using data reduction techniques, data presentation, conclusion, and clarification. The informant as the data source was chosen purposively.

The results of this study indicate that CV Wahana Putera Ideas has applied the sub-concept of Business Skill and Technology Skill in technopreneurship model as technopreneur. In the Business Skill sub-concept, Wahana Putera Ideas is a business entity with the form of a Comanditaire Venotschap or CV that has been implementing the concept of a manufacturing company and has made business plan as a corporation planning; The Company utilizes natural resources as production materials and production processes under the guidance of BSN; and the company selectively provides selective incentives to resellers by applying 1 channel to many markets. In the sub-concept of Technology Skill, CV Wahana Putera Ideas is the owner of the invention and product innovation that is ethanol+, and protects it with Patent Right with the application number P0020090345 named Invention of Electric-Based Gas Convertible Stove with Liquid Fuel (Non-Fossil) announced at Patent Office on December 30, 2010 with the publication number 050.6701 A. The conclusion of this research is that CV Wahana Putera Ideas has applied the concept of Technopreneurship in managing the company which is engaged in alternative energy business.
\end{abstract}

Keywords technopreneurship, business skill, technology skill, alternative, energy

\section{Introduction}

Realizing that Indonesia has abundant renewable energy, the government has always tried to utilize renewable energy through various ways. A former Minister of Energy and Mineral Resources (MESDM) Sudirman Said through his speech in Bali, on February 11, 2016 stated that "The government is aiming for a target of 25 percent or about 8.8 gigawatts $(\mathrm{GW})$ of power plants built from a power plant project of 35 thousand Megawatt (MW) comes from re- newable energy ". Furthermore, Sudirman Said that "Up to now, the progress of electricity construction had reached 17.3 GW, and 2.7 GW of which comes from renewable energy.

The governments strive in encouraging the development of new renewable energy among others making fundamental policies to encourage the realization of clean energy which is currently done, among others, by preparing the General Plan of National Energy (RUEN) with the target of renewable energy development by $46 \mathrm{GW}$ in 2025 . 
On the same occasion, Vice President (Jusuf Kalla) stated that many countries have the ability, but lacks technology. While many countries have technology, but do not have adequate natural resources. Jusuf Kalla said that Indonesia in this case is lucky, because it has a complete component in terms of renewable or clean energy. Furthermore, Jusuf Kalla stated that Indonesia has sufficient gas source, even for export to abroad. "For that potential gas will be easily utilized as well as possible for the future" (Ferial, 2012).

On the other side, the result of BPPT's observations shows that the final energy consumption in the household sector is $1.59 \%$ per year, the low growth of final energy consumption from the household sector is very unbalanced with other sectors due to various government programs, such as substitution program Kerosene with LPG for cooking, the application of energy-efficient technologies and equipment such as the use of energy-saving lamps, the use of solar cells, and the use of other energy-efficient household appliances, and the latest technology in the form of alternative energy, especially for household consumption.

Based on the above description, the researchers saw a link between technology and business. Researchers see the existence of problems that continue, in addition to the increasingly expensive gas prices currently sold by PT. PERTAMINA, also due to the increasing rare of gas cylinders, due to the ever-increasing growth of gas stoves. Another problem related to the use of gas for public consumption is that many LPG gas cylinders are exploding, especially $3 \mathrm{Kg}$ LPG gas which is the most widely used by society, that the middle to lower society, because the price is relatively affordable. Some of these problems encourage people to seek alternative of renewable energy.

The impact of some of the problems above, has encouraged people to find an alternative to meet the needs of cheap gas without being frightened by the fear of the explosion from explosive gas cylinders, and gas scarcity that can inhibit the activities of daily life.

On the other side, the development of technology with the main objective is to improve the welfare of the community through various facilities, has been seen by various parties to be the solution in solving the problems that arise related with the gas needs by community, especially the people who have the instinctive acumen in seeing of business opportunities. Parties who see this problem, furthermore combine technology with business opportunities.
In business concept, the integration of technology with business -often referred to as the entrepreneurial term-is known as technology entrepreneurship or technopreneurship.

"CV. Wahana Putera Ideas" as the object of this research is one of the technopreneurship based companies engaged in the field of appropriate alternative energy, in accordance with the initiative of this research, which is analyzing the application of technopreneurship in alternative energy companies. "CV. Wahana Putera Ideas" is the first supplier and retailer of gas stoves that can utilize technology in processing appropriate alternative energy in Indonesia. "CV. Wahana Putera Ideas" sells alternative energy products that can be used to meet consumer demand constrained by expensive gas and concerns over the tendency of gas cylinders that often explode.

Earlier observation as a preliminary study, conducted by researchers through interviews with Managing Director "CV. Wahana Putera Ideas" on January 15, 2017, Wahono Handoko. From this interview it was revealed that this business was initiated by searching for renewable energy sources, to meet people's need for cooking. The company continues to innovate, so that successfully created products that looks like a regular stove. This is done by the company to make its products easy to be known by people, according to its function.

\section{Literature Review}

Generally, entrepreneurial experts mention that technological entrepreneurship or technopreneurship is a business involving technology for the development of the products that produces. Various innovations and technology-based creativity become a strategy in exploiting business opportunities. Technopreneurship is the development of entrepreneurship.

Entrepreneurship, according to Jati and Priyambodo (2015) essentially is taking advantage of opportunities and make a profit. While Technopreneurship, according to Diharjo, et al. (2014), is technology-based entrepreneurship, that is entrepreneurship resulting from science, technology, and engineering required by the market. The Agency for the Assessment and Application of Technology (BPPT) as a related government institution, states that technological entrepreneurship or technopreneurship can be defined as entrepreneurship whose business activities are based on 
technology (BPPT, 2010)

Hamid (2011) argues that technological entrepreneurship is a business skill that is enriched with technological skills, so that it can mastering the concept and theory of the technology-based entrepreneurship. Business skills include: Business Plan, Entrepreneurship, Company Form, and Marketing. While technology skills include: Invention and Innovation, Mechanism of Technology Market, Intellectual Property Management / HAKI, Product Design, and Packaging.

The literature review in this research is more function as the subject matter of the study, which perhaps the differences can occur in the practice in the field. These differences will be part of the researchers' strength of analysis from this study.

\subsection{Business Skill}

Business skill is the skills that owned by a person to discover, evaluate and develop some business activities that aims to make a profit. The matters relating with the business skills is included several dimensions, consists of:

\section{a. Business Plan}

It is the most time-consuming stage in the entrepreneurial process. The main and most important components of the business plan include: Business Description, Industry Description, Technology Plan, Marketing Plan, Financial Plan, Production Plan, Organizational Plan, and Operation Plan (Hisrich, et.al, 2008: 14).

b. Entrepreneurship

This process has four distinct phases: (1) identifying and evaluating opportunities, (2) developing a business plan, (3) determining the resources needed, and (4) managing the resulting firm (Hisrich, et.al, 2008: 11).

c. Company Form

There are three forms of legal business formation and one new form with limited liability. The three basic legal forms are: 1) individual companies, 2) partnerships, and 3) corporations. Company forms generally apply variations between partnerships and corporations. The latest form of business formation is a limited liability company (LLC).

d. Marketing

An entrepreneur can develop a marketing strategy plan and action plan. These strategy and action decisions are reflected in the marketing mix, which consists of several variables. Some possible decisions that can be made for each of these variables include:

1) Products or Services

These products include packaging, brand name, price, warranty, image, service, delivery time, various features, styles and even websites to be seen by most customers.

2) Pricing

Before setting a price, in most situations, employers need to consider three important elements: cost, margin or price increases, and competition.

3) Distribution

This aspect provides utility to the consumer, that is, the aspects that make a product easy to buy when needed.

4) Promotion

Entrepreneurs usually need to inform to potential customers of product availability or to educate consumers by using print advertising media, radio, or television (Hisrich, at.al, 2008: 325).

\subsection{Technology Skill}

Technology skill that is managerial skill in following and mastering various technological developments that occur. The matters relating to the technology skills include several dimensions, among others things:

\section{a) Invention and Innovation}

Invention is a discovery of something new that aims to simplify life, Innovation is the process of adoption of a discovery by market mechanisms. Invention and innovation are of two types: (1) product invention and innovation, and (2) invention and innovation in processes.

\section{b) Technology Market Mechanism}

Hariyati (2014: 2) argues that the demand and supply is also called the market mechanism, therefore the sense of demand is the desire of consumers to buy a good at various price levels for a certain period of time, accompanied by the willingness and ability to buy the goods. While understanding of the offer is the amount of goods that manufacturers want to offer (sell) at various price levels during a certain period. 
c) Intellectual Property Management (Intellectual Property Rights/IPR)

The basic elements of IPR include the scope of work of any type that is protected, substantive requirements, how to obtain it, the contents and the period of validity of IPR protection. The basic elements of IPR are Copyrights, Patents, Trademarks, and Trade Secrets.

d) Production design

An industrial design is a creation of the shape, configuration, or composition of lines or colors, or lines and colors or combinations thereof which are 3-dimensional or 2-dimensional which provide aesthetics and can be manifested in 3-dimensional or 2-dimensional patterns and can be used to produce products, Goods, commodities, industries or handicrafts.

e) Packaging

Packaging is a pack of products that received by consumers, whereas packing is a pack of number of products and which usually accepted by an agent or supplier.

\section{Research Framework And Proposition}

Based on the background described in the Literature Review, technopreneurship is built through a business enriched with technology skills, so that entrepreneurs can master both business skills and technology skills. Business skills include: Business Plan, Entrepreneurship, Corporation, and Marketing, while technology skills include: Invention and Innovation, Technology Market Mechanism, Intellectual Property Management (IPR), Production Design, and Packaging.

The proposition of this research is that the operational management of "CV. Wahana Putera Ideas" related with Technopreneurship to become survive and competitive company. Furthermore, based on these references the research framework can be seen in Figure 1 below.

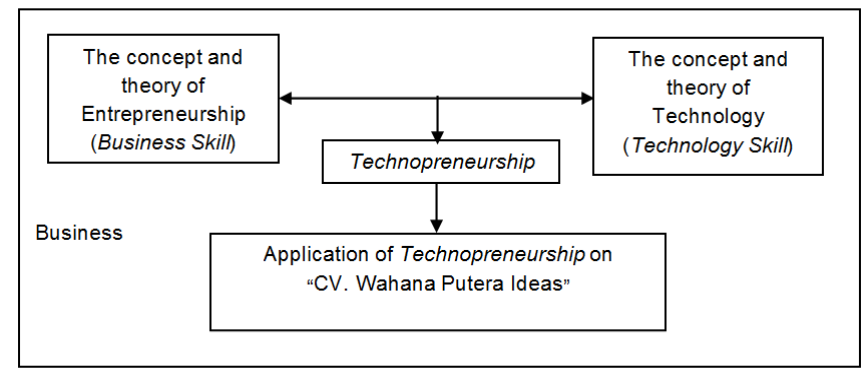

Figure 1. Research Framework

\section{Research Methodology}

The type of this research is descriptive with qualitative approach. Data collection techniques used observation, interviews, and related document collection, whereas processing and data analysis using data reduction techniques, data presentation, conclusions, and clarification. The informant as the data source was chosen purposively. In this research, the researcher is as the key instrument, and the data analysis is inductive/ qualitative, with the result of research more emphasis on meaning (Sugiyono, 2013: 9).

\section{Informant}

According to Newman (2015: 499), an informant in qualitative research is a person who deals with field researchers and who says, or informs, about the truth of something occurred in the field, related with this research. Furthermore, Newman says that the good informants are non-analytical individuals who use pragmatic common sense. The ideal informant in this study has four characteristics: that is familiar with the company's operations, still involved in the field, can spend time for the researcher, and can express his opinion pragmatically. Therefore, the researcher chose the informants who meet the criteria in this study, there are:

a) President Director of "CV. Wahana Putera Ideas",

b) Strategic Manager of "CV. Wahana Putera Idea",

c) Financial Manager of "CV. Wahana Putera Ideas",

d) Production and Maintenance Manager of " $\mathrm{CV}$. Wahana Putera Ideas", and

e) Workers in the assembly department of "CV. Wahana Putera Ideas".

\section{Data Source and Data Collection Technique}

The sources of data that used in this study are primary sources and secondary sources. The primary data source is the result of interview with the leaders and or employees of "CV. Wahana Putera Ideas" which have been chosen to be informants purposively, either in the form of sound recording, video, or picture. While the secondary data source is 
obtained from the website "CV. Wahana Putera Ideas" www.komporgastrik.com, among others in the form of pictures and product description, logo, and how to order their products.

In the process of data collection, the researchers use triangulation technique, that is data collection techniques that combine from various techniques of data collection from data sources. Researchers use different data collection techniques to obtain data from the same source, that is participatory observation, in-depth interviews and documentation for the same data and then processing data simultaneously.

\section{Test Validity and Reliability}

The Researcher use triangulation technique and checking to test validity and reliability, that is by collecting interview result, observation and other documentation like recording and picture. Furthermore, information that has been obtained from various sources is re-confirm to informants.

\section{Processing Techniques and Data Analysis}

In the technique of processing and data analysis, researchers use Miles and Huberman model. In the processing and data analysis model Miles and Huberman (1994: 12), contains four interrelated components, there are: 1) Data collection; 2) Data reduction / simplification, including: grouping and sorting of data; 3) Data exposure; and 4) Conclusions and testing conclusions.

Illustrations of the model are as follows:

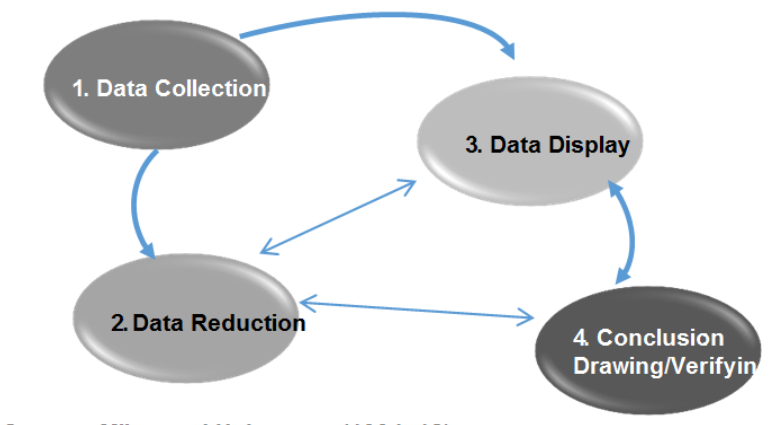

Source: Miles and Huberman (1994: 12)

Figure 2 Component of Data Analysis: Interactive Model

\section{Discussion}

\section{Business Skill Applications Table 1}

Table 1 Business Skill Applications on "CV. Wahana Putera Ideas"

\begin{tabular}{|c|c|c|}
\hline NO. & DIMENSIONS & APPLICATIONS \\
\hline 1. & $\begin{array}{l}\text { Entrepreneur- } \\
\text { ship }\end{array}$ & $\begin{array}{l}\text { Application of Entrepreneurship at "CV. } \\
\text { Wahana Putera Ideas", starting from the } \\
\text { identification and evaluation of the existing } \\
\text { opportunities by the company with looking at } \\
\text { the public's dependence on government } \\
\text { subsidies related to the high price of LPG gas, } \\
\text { and utilization of natural resources "sor- } \\
\text { ghum" which can be utilized as an alternative } \\
\text { energy source. In the aspect of developing its } \\
\text { business plan, the company does it through } \\
\text { market observation, target market and fuel } \\
\text { innovation. In the aspect of business man- } \\
\text { agement, the company's strategy is to change } \\
\text { the mindset of LPG gas subsidy to renewable } \\
\text { alternative energy business, by continuously } \\
\text { evaluating and Research \& Development (R } \\
\text { \& D) for the diversity and perfection of } \\
\text { stoves and other fuel variants. }\end{array}$ \\
\hline 2. & Business Plan & $\begin{array}{l}\text { "CV. Wahana Putera Ideas" have created a } \\
\text { Business Plan, including: business descrip- } \\
\text { tion, industry description, technology plan, } \\
\text { marketing plan, financial plan, production } \\
\text { plan, organizational plan, and operating plan. } \\
\text { Business Plan made by CV. "Wahana Putera } \\
\text { Ideas", referring to "Ciputra" standardization, } \\
\text { as one of the big companies in Indonesia. }\end{array}$ \\
\hline 3. & Marketing & $\begin{array}{l}\text { All of products are sold, directed to obtain } \\
\text { ISO } 9001 \text { quality standard and supervised by } \\
\text { National Standardization Body (BSN), so } \\
\text { that the quality of product is controlled. } \\
\text { Profit margin set by } 25 \%-30 \% \text {, while the } \\
\text { basic analysis for the pricing, in addition to } \\
\text { the calculation of production cost is also the } \\
\text { purchasing power of the community and } \\
\text { competition between competitors. In the } \\
\text { distribution aspect, the company implements } \\
\text { selective incentive to the resellers, and im- } \\
\text { plements } 1 \text { (one) channel for many markets, }\end{array}$ \\
\hline
\end{tabular}


Table 1. cont

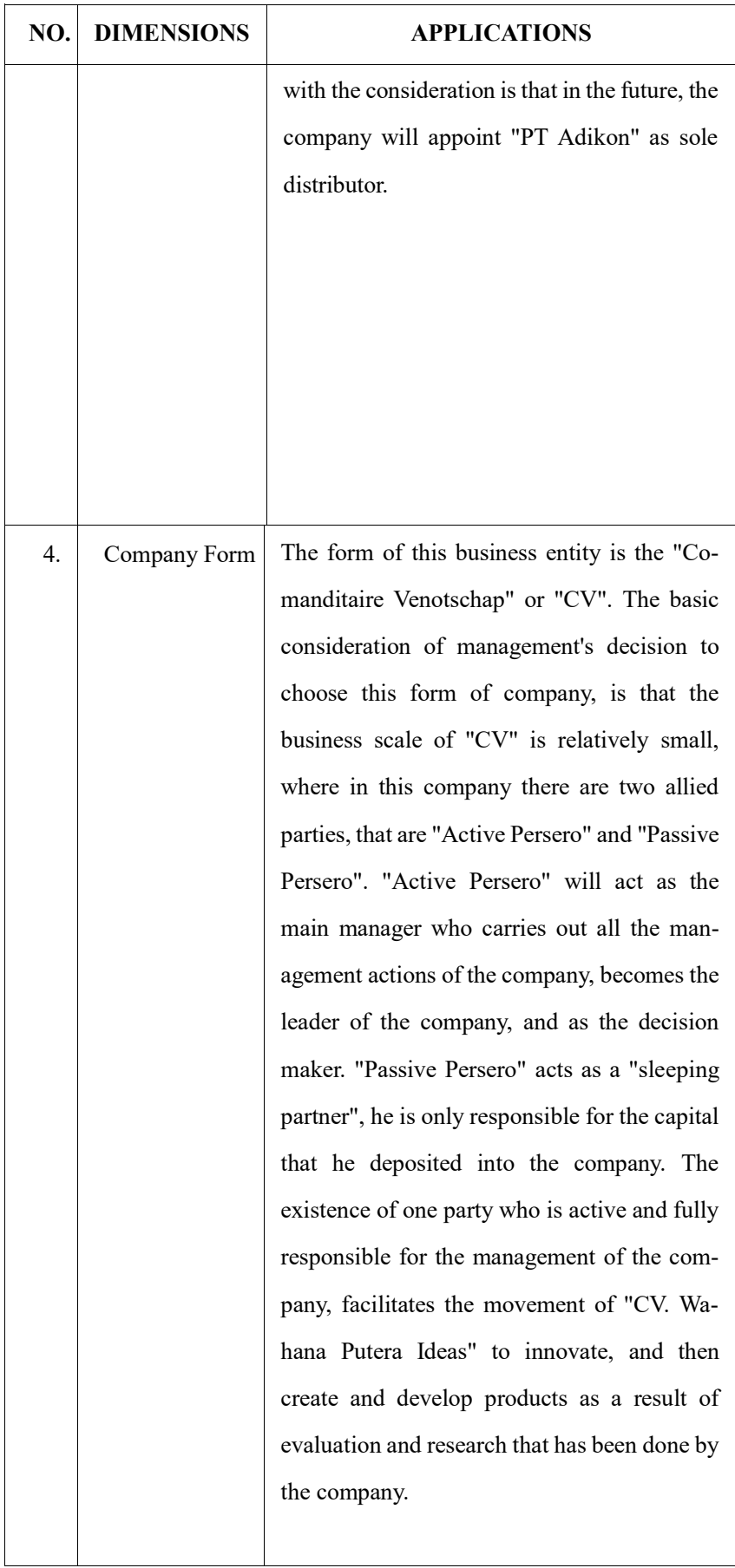

\section{Technology Skill Applications Table 2}

Table 2 Technology Skill Application on "CV.

Wahana Putera Ideas"

\begin{tabular}{|c|l|c|}
\hline NO. & DIMENSION & \multicolumn{1}{|c|}{ APPLICATION } \\
\hline 1. & $\begin{array}{l}\text { Invention and } \\
\text { Innovation }\end{array}$ & $\begin{array}{l}\text { "CV. Wahana Putera Ideas" have product } \\
\text { invention and innovation that is ethanol+ as } \\
\text { base material of company product. The process } \\
\text { undertaken by the company, both for product }\end{array}$ \\
\hline
\end{tabular}

Table 2. cont

\begin{tabular}{|c|c|c|}
\hline No. & DIMENSION & APPLICATION \\
\hline & & $\begin{array}{l}\text { invention and innovation, is directed to pro- } \\
\text { cesses referring to ISO } 9001 \text {. }\end{array}$ \\
\hline 2. & $\begin{array}{l}\text { Technology } \\
\text { Market } \\
\text { Mechanism }\end{array}$ & $\begin{array}{l}\text { In addition to selling its products through a } \\
\text { single distributor, "CV. Wahana Putera Ideas" } \\
\text { has also offered services in related technology } \\
\text { areas, such as agricultural land production, } \\
\text { consulting services with modern farming } \\
\text { methods, and fractional distillation machines. } \\
\text { The demand for some of these related tech- } \\
\text { nology services arose, because according to the } \\
\text { people the application of the technology made } \\
\text { it easier for them to do the work. }\end{array}$ \\
\hline 3. & $\begin{array}{l}\text { Intellectual } \\
\text { Property } \\
\text { Management }\end{array}$ & $\begin{array}{l}\text { CV. Wahana Putera Ideas had protected } 2 \\
\text { elements of products invention and innovation } \\
\text { and registered it to the Ministry of Justice and } \\
\text { Human Rights of the Republic of Indonesia, } \\
\text { Directorate General of Intellectual Property } \\
\text { Rights. Elements of Corporate Invention and } \\
\text { Innovation that have been patented are Patent } \\
\text { Rights with application number P0020090345 } \\
\text { under the title of Invention of Electrici- } \\
\text { ty-Based Convertible Gas Stove with Liquid } \\
\text { Fuel (Non-Fossil) announced at Patent Office } \\
\text { on } 30 \text { December } 2010 \text { with publication num- } \\
\text { ber } 050.6701 \text { A. }\end{array}$ \\
\hline 4. & Packaging & $\begin{array}{l}\text { Results of product from "CV. Wahana Putera } \\
\text { Ideas" are packed after the stove has been } \\
\text { assembled and finished, the stove is inserted } \\
\text { into a large plastic then after that inserted into } \\
\text { the cardboard. Different with other packing for } \\
\text { fuel, for bio-ethanol fuels it is put in a } 1.5 \text {-liter } \\
\text { plastic bottle. }\end{array}$ \\
\hline
\end{tabular}




\section{Conclusion}

Based on the discussion above, the researcher concludes that "CV. Wahana Putera Ideas" has applied the business concept of technopreneurship in the management of the company. Management of "CV. Wahana Putera Ideas" based on the concept of technopreneurship is shown by the fact that the company has implemented the two main concepts of technopreneurship. The company's ability to see and capture business opportunities in the form of community's need for relatively cheap and safe of renewable energy, it shows that the company has a good business skill. While the company's ability to create invention and technology-based innovation in the form of ethanol+ as basic material of product that developed as its business base, indicating that the company also has good technology skills in this field. Application of technopreneurship concept on "CV. Wahana Putera Ideas", has successfully been positioning the company to survive and even grow in the midst of business competition.

\section{REFERENCES}

[1] BPPT. 2010b. "Naskah Akademis Kebijakan Pengembangan Technopreneurship." Mimeo, Pusat Pengkajian Kebijakan Peningkatan Daya Saing. Jakarta, Indonesia.

[2] Diharjo, Kuncoro dan Wahyudi Sutopo. 2014. Kewirausahaan Berbasis Teknologi

[3] (Technopreneurship). UNS Press. Surakarta, Indonesia.

[4] Hamid. (2011), Pengembangan "Technopreneurship" Di Perguruan Tinggi Dan Implikasi Kebijakannya. Jurnal Sains dan Teknologi. 13(1), 43-48.

[5] Hisrich, Robert D., Peters, Michael P., \& Shepherd, Dean A. (2008). Entrepreneurship:

[6] Kewirausahaan (7th ed.). Salemba Empat, Jakarta.

[7] Jati, Bambang Murdaka Eka \& Priyambodo, Tri Kuntoro. (2015). Kewirausahaan

[8] Technopreneurship Untuk Mahasiswa Ilmu - Ilmu Exacta. Andi Yogyakarta. Yogyakarta, Indonesia.

[9] Miles, M. B., \& Huberman, A. M. (1994). Qualitative data analysis: An expanded sourcebook (2nd ed.). Thousand Oaks, CA: Sage.

[10] Newman, W. Lawrence, 2015. Metodologi Penelitian Sosial: Pendekatan Kualitatif dan Kuantitatif. Edisi 7. PT. Indeks, Jakarta, Indonesia.

[11] Sugiyono. (2013). Memahami Penelitian Kuantitatif Kualitatif dan R\&D. Alfabeta. Bandung, Indonesia.

[12] Suparno, Ono., Hermawan, Aji., \& Syuaib, M. Faiz. (2008) Technopreneurship. Recognition and Mentoring Program-Institut Pertanian Bogor (RAMP-IPB), Diakses tanggal 5 Maret 2017, dari http://ono.suparno.staff.ipb.ac.id.
[13] www.komporgastrik.com Tentang Kompor Gastrik, diakes tanggal 22 Januari 2017.

[14] www.googlemaps.com. Situs Lingkungan Industri Kecil, Jalan Soekarno Hatta Km 12,5 Blok E no 3 Gede Bage Bandung, diakses tanggal 22 Januari 2017. 